\title{
Cation-Exchange Porosity Tuning in Anionic Metal-Organic Frameworks for the Selective Separation of Gases and Vapors and for Catalysis**
}

\author{
Elsa Quartapelle Procopio, Fátima Linares, Carmen Montoro, Valentina Colombo, \\ Angelo Maspero, Elisa Barea, and Jorge A. R. Navarro*
}

The outperforming adsorptive properties of the so-called open metal-organic frameworks (MOFs) or porous coordination polymers (PCPs) rely on their fully accessible porous structure and the easy tuning of the shape, size, and chemical nature of their pores. ${ }^{[1-3]}$ The ability of some of these systems to mimic the structure and properties of zeolites has also been realized. ${ }^{[4-6]}$ There are, however, unsolved problems related to the general lower thermal and chemical stability (hydrolysissensitive nature) of $\mathrm{MOFs}^{[7]}$ compared to their zeolite counterparts. Consequently, the search for highly robust MOFs capable of withstanding the working conditions typically found in industrial processes is a highly desirable challenge. In this regard, the robustness of the metal-nitrogen(heterocycle) coordinative bonds leads to the formation of MOF materials with enhanced chemical and thermal stabilities. $^{[8]}$ It should also be noted that, in contrast to the wellknown cation-exchange features of zeolites, the zeomimetic coordination polymers generally possess neutral or cationic frameworks and consequently do not usually give rise to cation-exchange processes. ${ }^{[9]}$

Herein, we report the synthesis, structural characterization, thermal/chemical stability, and adsorptive, separation, and catalytic properties of the anionic MOF $\mathrm{NH}_{4}\left[\mathrm{Cu}_{3}-\right.$ $\left.\left(\mu_{3}-\mathrm{OH}\right)\left(\mu_{3}-4 \text {-carboxypyrazolato }\right)_{3}\right] \quad\left(\mathrm{NH}_{4} @ \mathbf{1}\right)$. In addition, we have examined the plausible modulation of its porous network by means of ion-exchange processes of the extraframework cations. The results show that the ion-exchange

[*] E. Quartapelle Procopio, Dr. F. Linares, C. Montoro, Dr. E. Barea, Prof. J. A. R. Navarro

Departamento de Química Inorgánica, Universidad de Granada

Av. Fuentenueva S/N, 18071 Granada (Spain)

Fax: $(+34) 958-248526$

E-mail: jarn@ugr.es

Homepage: http://www.ugr.es/local/jarn

V. Colombo, Dr. A. Maspero

Dipartimento di Scienze Chimiche e Ambientali

Università dell'Insubria

Via Valleggio 11, 22100 Como (Italy)

[*** E.Q.P. and F.L. contributed equally to this work. Support by the Spanish MCINN (grant CTQ2008-00037/PPQ and Ramón y Cajal contract (E.B.)), Junta de Andalucía, and EU (NanoMOF-228604) is acknowledged. The authors are gratefully indebted to Prof. D. Proserpio (Univ. Milan) for his help with the framework topological analysis.

Supporting information for this article (experimental methods, thermal analysis, chemical stability tests, ion exchange, vapor adsorption selectivity, catalysis) is available on the WWW under http://dx.doi.org/10.1002/anie.201003314. processes on these systems lead to profound changes in the textural properties of their porous surface and in the adsorption selectivity of different separation processes of gases and vapors.

The crystal structure of $\mathrm{NH}_{4} @ \mathbf{1}^{[10]}$ is based on an anionic $3 \mathrm{D}$ porous framework built up of trinuclear $\mathrm{Cu}_{3}\left(\mu_{3}-\mathrm{OH}\right)$ clusters connected to another six through $\mu_{3}$-4-carboxypyrazolato bridges (Figure 1). In this way, tetrahedral cages with

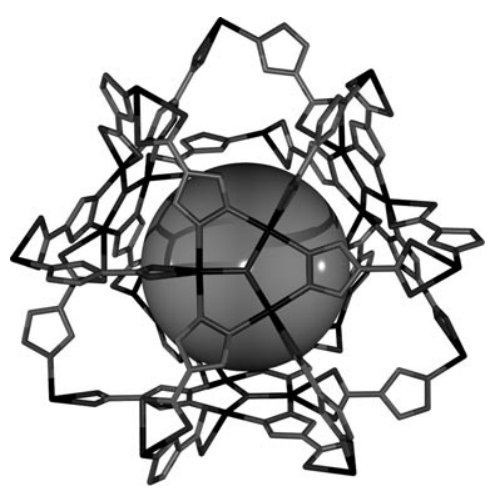

Figure 1. View of the tetrahedral cages found in the crystal structure of $\mathrm{NH}_{4} @ 1$. The sphere indicates the size of the inner void.

an inner diameter of about $13 \AA$ are generated, which host two extraframework $\mathrm{NH}_{4}{ }^{+}$cations and water of crystallization molecules. Calculations with Platon, ${ }^{[11]}$ after removal of the hosted water molecules, give rise to a high potentially accessible empty volume that accounts for approximately $49 \%$ of the crystal cell. The tetrahedral voids are threedimensionally connected through windows 4.5 and $8 \AA$ in width along the [100] and [111] crystallographic directions, respectively (Figure 2). Overall, the $\mathrm{NH}_{4} @ \mathbf{1}$ framework is
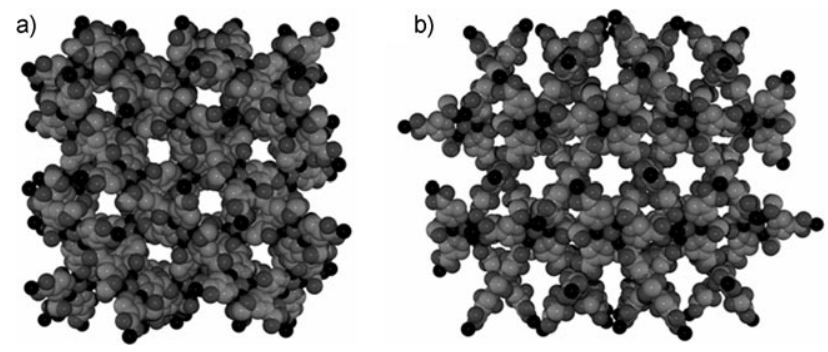

Figure 2. Space-filling view of the crystal structure of $\mathrm{NH}_{4} @ 1$ along the crystallographic [100] (a) and [111] (b) directions. 
reminiscent of that found in the $\left[\mathrm{Cu}_{3}\left(\mu_{3}-\mathrm{OH}\right)\right.$ (4-pyridyltetrazolato $\left.)_{3}(\mathrm{OH})_{2}(\mathrm{DMF})_{4}\right]$ system reported by Zubieta and co-workers; ${ }^{[12]}$ however, in our case the framework is anionic whereas in the latter it is neutral. Taking the $\mathrm{Cu}_{3}\left(\mu_{3}-\mathrm{OH}\right)$ structural motifs as nodes of the framework, the structure can be described as hxg-type topology with the $\left\{4^{6} \cdot 6^{9}\right\}$ point symbol and the $\left[4.4 .4 .4 .4 \cdot 4 \cdot 6_{4} \cdot 6_{4} \cdot 6_{4} \cdot 6_{6} \cdot 6_{6} \cdot 6_{6} \cdot 6_{6} \cdot 6_{6} \cdot 6_{6}\right]$ vertex symbol. ${ }^{[13]}$

We performed a series of chemical stability tests and thermal assays to establish the robustness of the $\mathrm{NH}_{4} @ \mathbf{1}$ material. The results show that the system remains unaltered in boiling organic solvents (methanol, benzene, cyclohexane), in aqueous solution (up to $353 \mathrm{~K}$, for $4 \mathrm{~h}$ ), and at room temperature in dilute acidic $\left(0.001 \mathrm{M} \mathrm{HNO}_{3}\right.$, for $\left.4 \mathrm{~h}\right)$ or basic $(0.001 \mathrm{M} \mathrm{NaOH}$, for $4 \mathrm{~h})$ aqueous solutions (see the Supporting Information). On the other hand, the thermal analysis of this material (thermogravimetric analysis, differential scanning calorimetry, and thermal X-ray powder diffraction (XRPD)) is indicative of its sequential dehydration in the $313-408 \mathrm{~K}\left(-8 \mathrm{H}_{2} \mathrm{O}\right)$ and $423-453 \mathrm{~K}\left(-\mathrm{H}_{2} \mathrm{O}\right)$ ranges with the framework remaining stable, in air, up to $553 \mathrm{~K}$. The thermal XRPD studies show that the framework does not undergo significant stress during heating, with a $\delta \ln V / \delta T$ value of $-4.8 \times 10^{-5} \mathrm{~K}^{-1}$, which suggests a slight cell contraction concomitant to the dehydration process. Notably, the dehydration process is also accompanied by the occurrence of new reflections, above $363 \mathrm{~K}$, indicative of a newborn phase (probably a superlattice). This process is reversed upon lowering the temperature and after exposure of the material to the open air at room temperature, which leads to the original hydrated material in a few hours.

We also examined the exchangeable nature of the extraframework $\mathrm{NH}_{4}^{+}$cations as a way to modulate the porous structure of this material. Indeed, the suspension of $\mathrm{NH}_{4} @ 1$ in $0.1-0.5 \mathrm{M}$ aqueous solutions of $\mathrm{ANO}_{3}$ salts $\left(\mathrm{A}=\mathrm{Li}^{+}\right.$, $\mathrm{Na}^{+}, \mathrm{K}^{+}, \mathrm{Ca}^{2+} / 2, \mathrm{La}^{3+} / 3$ ) or $0.5 \mathrm{M}$ methanolic solutions of organic amines $\left(\mathrm{Me}_{3} \mathrm{~N}, \mathrm{Et}_{3} \mathrm{~N}\right)$ gives rise to the exchanged $\mathrm{A}_{x}\left(\mathrm{NH}_{4}\right)_{1-x}\left[\mathrm{Cu}_{3}\left(\mu_{3}-\mathrm{OH}\right)\left(\mu_{3}-4 \text {-carboxypyrazolato }\right)_{3}\right] \quad$ (A@1) systems $\left(\mathrm{A}=\mathrm{Li}^{+}, \mathrm{Na}^{+}, \mathrm{K}^{+}, \mathrm{Me}_{3} \mathrm{NH}^{+}, \mathrm{Et}_{3} \mathrm{NH}^{+}, x=0.5 ; \mathrm{A}=\right.$ $\left.\mathrm{Ca}^{2+} / 2, \mathrm{La}^{3+} / 3, x=1\right)$ which show unaltered XRPD patterns according to the maintenance of the anionic 1 framework (see the Supporting Information). $\mathrm{N}_{2}$ adsorption measurements performed on the exchanged systems show profound changes in the adsorption isotherms concomitant to the ion-exchange processes, which are indicative of the modulation of the porosity of $\mathbf{1}$ (Figure 3 ). Indeed, on passing from $\mathrm{NH}_{4}^{+}$to $\mathrm{Et}_{3} \mathrm{NH}^{+}$a lowering of the adsorption capacity and pore surface is observed (the Brunauer-Emmett-Teller (BET) surface area of $680 \mathrm{~m}^{2} \mathrm{~g}^{-1}$ for $\mathrm{NH}_{4} @ \mathbf{1}$ diminishes to 505 and $510 \mathrm{~m}^{2} \mathrm{~g}^{-1}$ for $\mathrm{Me}_{3} \mathrm{NH} @ \mathbf{1}$ and $\mathrm{Et}_{3} \mathrm{NH} @ \mathbf{1}$, respectively). This result agrees with a reduction of the accessible pore volume as a consequence of the bulkier nature of $\mathrm{R}_{3} \mathrm{NH}^{+}$ions compared to $\mathrm{NH}_{4}^{+}$.

We also examined the effect of the ion-exchange processes on the separation selectivity by adsorption of gases of environmental and industrial interest $\left(\mathrm{N}_{2}, \mathrm{CH}_{4}, \mathrm{CO}_{2}, \mathrm{C}_{2} \mathrm{H}_{2}\right)$ and harmful vapors (benzene, cyclohexane). $\mathrm{CO}_{2} / \mathrm{C}_{2} \mathrm{H}_{2}$ as well as benzene/cyclohexane mixtures are difficult to separate as a consequence of their similar physical properties, and con-

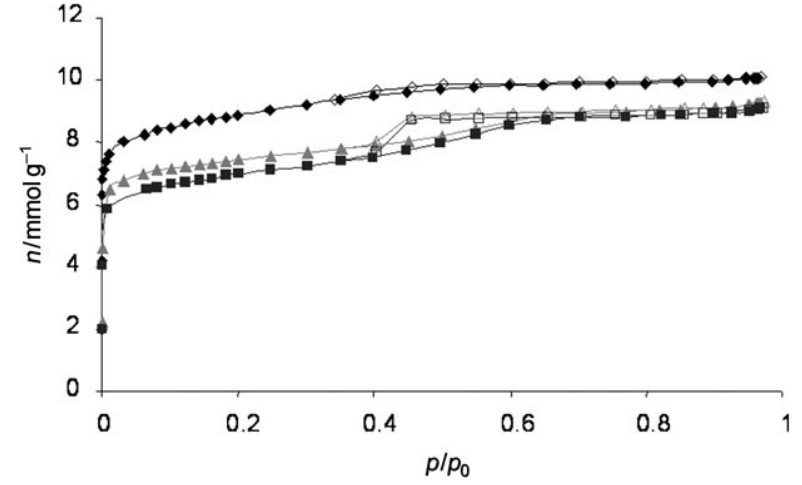

Figure 3. Cation-exchange modulation of the porous network in $\mathrm{A} @ 1$ systems $\left(\mathrm{A}=\mathrm{NH}_{4}{ }^{+}, \mathrm{Me}_{3} \mathrm{NH}^{+}, \mathrm{Et}_{3} \mathrm{NH}^{+}\right)$as shown by $\mathrm{N}_{2}$ adsorption isotherms at $77 \mathrm{~K} . \mathrm{NH}_{4} @ 1(\bullet), \mathrm{Me}_{3} \mathrm{NH} @ 1(\Delta), \mathrm{Et}_{3} \mathrm{NH} @ 1$ (घ). Open symbols denote desorption.

sequently it is of interest to find methods for their efficient separation. ${ }^{[14]}$

Variable-temperature pulse gas chromatography experiments were carried out in the $273-363 \mathrm{~K}$ temperature range with a complex gas mixture $\left(\mathrm{N}_{2}, \mathrm{CH}_{4}, \mathrm{CO}_{2}, \mathrm{C}_{2} \mathrm{H}_{2}\right)$ to examine the possible utility of these systems for gas separation purposes (Figure 4). The results show that the $\mathrm{A} @ \mathbf{1}(\mathrm{A}=$
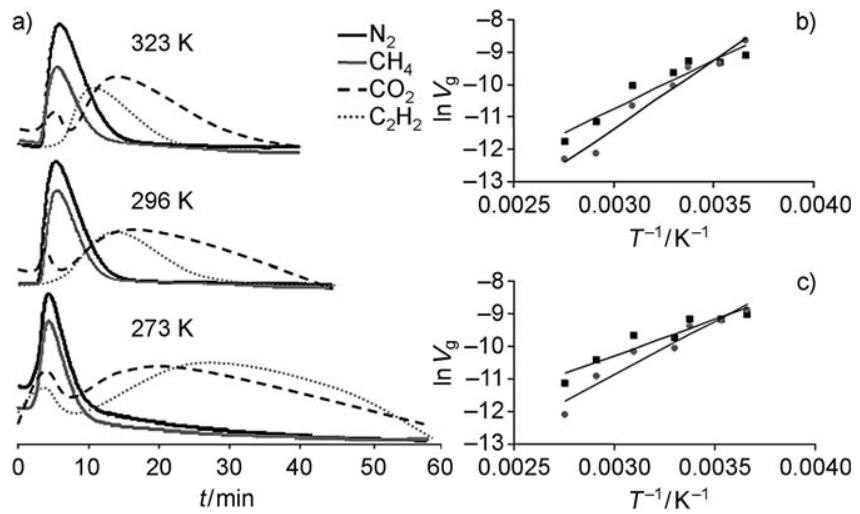

Figure 4. a) Variable-temperature pulse gas chromatography experiments of an equimolecular $\mathrm{N}_{2} / \mathrm{CH}_{4} / \mathrm{CO}_{2} / \mathrm{C}_{2} \mathrm{H}_{2}$ gas mixture passed through a chromatographic column packed with $\mathrm{NH}_{4} @ 1$ using a $\mathrm{He}$ flow of $10 \mathrm{~mL} \mathrm{~min}^{-1}$. b,c) Variation of $\mathrm{CO}_{2}$ (squares) and $\mathrm{C}_{2} \mathrm{H}_{2}$ (circles) retention volumes $\mathrm{V}_{\mathrm{g}}\left[\mathrm{m}^{3} \mathrm{~g}^{-1}\right]$ on $\mathrm{NH}_{4} @ 1$ (b) and $\mathrm{Et}_{3} \mathrm{NH} @ 1$ (c) as a function of adsorption temperature (273-363 K).

$\mathrm{NH}_{4}{ }^{+}, \mathrm{Et}_{3} \mathrm{NH}^{+}$) frameworks give rise to significant interactions with acetylene and carbon dioxide, whereas the interactions with nitrogen and methane are negligible. Notably, at low temperatures $(T<286 \mathrm{~K})$, acetylene is more tightly retained by A@1 frameworks than carbon dioxide. At higher temperatures $(\mathrm{T}>286 \mathrm{~K})$ the reverse situation is found, with $\mathrm{C}_{2} \mathrm{H}_{2}$ being eluted before $\mathrm{CO}_{2}$ (Figure $4 \mathrm{a}$ ). This can be visualized in the $\ln V_{\mathrm{g}}$ versus $1 / T$ graphs $\left(V_{\mathrm{g}}=\right.$ gas retention volume) showing the intersection of the $\mathrm{CO}_{2}$ and $\mathrm{C}_{2} \mathrm{H}_{2}$ tendency lines at about $286 \mathrm{~K}$, the temperature at which $\mathrm{CO}_{2} / \mathrm{C}_{2} \mathrm{H}_{2}$ separation becomes ineffective. 
The zero-coverage heats of adsorption $\left(\Delta H_{\mathrm{ads}}\right)$ for $\mathrm{CO}_{2}$ and $\mathrm{C}_{2} \mathrm{H}_{2}$ were calculated from the slope of the plots of $\ln V_{\mathrm{g}}$ versus $1 / T$ (Figure $4 \mathrm{~b}$ and c) according to $\Delta H_{\text {ads }}=-R \delta\left(\ln V_{\mathrm{g}}\right) /$ $\delta(1 / T)$, as indicated in reference [15], and the results are summarized in Table 1 . These $\Delta H_{\mathrm{ads}}$ values are similar to

Table 1: Calculated heats of adsorption $\Delta H_{\text {ads }}$, Henry constants $K_{\mathrm{H}}$, and partition coefficients $K_{\mathrm{r}}$ for $\mathrm{CO}_{2}$ and $\mathrm{C}_{2} \mathrm{H}_{2}$ from variable-temperature zero-coverage gas chromatography experiments on $\mathrm{NH}_{4} @ 1$ and $\mathrm{Et}_{3} \mathrm{NH}$ @1.

\begin{tabular}{lll}
\hline & $\mathrm{NH}_{4} @ 1$ & $\mathrm{Et}_{3} \mathrm{NH} @ 1$ \\
\hline$-\Delta H_{\text {ads }} \mathrm{C}_{2} \mathrm{H}_{2}\left[\mathrm{k} / \mathrm{mol}^{-1}\right]$ & 34.9 & 27.3 \\
$-\Delta H_{\text {ads }} \mathrm{CO}_{2}\left[\mathrm{~kJ} \mathrm{~mol}^{-1}\right]$ & 24.7 & 18.4 \\
$K_{\mathrm{H}} \mathrm{C}_{2} \mathrm{H}_{2}\left[\mathrm{~cm}^{3} \mathrm{~m}^{-2}\right]^{[a]}$ & 0.358 & 0.325 \\
$K_{\mathrm{H}} \mathrm{CO}_{2}\left[\mathrm{~cm}^{3} \mathrm{~m}^{-2}\right]^{[a]}$ & 0.225 & 0.280 \\
$\ln K_{\mathrm{r}}^{[a]}$ & 4.51 & 3.92 \\
\hline
\end{tabular}

[a] Calculated values at $273 \mathrm{~K}$.

those reported by Kitagawa and others for MOFs with narrow basic pores, obtained from monocomponent adsorption isotherms by applying the Clausius-Clapeyron equation. ${ }^{[16]}$ In this regard, these authors indicated the possible utility of this type of microporous network for the separation of $\mathrm{C}_{2} \mathrm{H}_{2} / \mathrm{CO}_{2}$ mixtures but no experiments were performed to demonstrate it. Consequently, we report (to the best of our knowledge for the first time) the utility of MOFs for this difficult separation process, thus highlighting the importance of the adsorption temperature in the efficiency of the separation (see above).

Moreover, the discrimination of the A@1 systems towards the $\mathrm{C}_{2} \mathrm{H}_{2} / \mathrm{CO}_{2} / \mathrm{CH}_{4}$ mixture might be of interest for the purification of acetylene obtained from partial burning of methane and oxygen. The efficiency of the separation is probably a consequence of a good balance of polarity gradients of the ionic structure, basic sites (carboxylates), coordination-unsaturated metal ions, H-bonding, and size of the cavities. ${ }^{[14]}$ In this regard, the separation coefficients $\left(K_{\mathrm{r}}\right)$ calculated for a binary mixture according to $\ln K_{\mathrm{r}}=$ $\left(\Delta H_{\mathrm{ads} 1}-\Delta H_{\mathrm{ads} 2}\right) / R T^{[17]}$ are large enough to ensure separation of $\mathrm{C}_{2} \mathrm{H}_{2} / \mathrm{CO}_{2}$ (Table 1). Moreover, in the case of $\mathrm{C}_{2} \mathrm{H}_{2} / \mathrm{CH}_{4}$ or $\mathrm{CO}_{2} / \mathrm{CH}_{4}$ mixtures the separation coefficients are expected to be nearly infinite.

Measurements of breakthrough curves of a 0.27:0.73 (v/v) mixture of $\mathrm{CO}_{2} / \mathrm{CH}_{4}$ flowed through a chromatographic column packed with $\mathrm{NH}_{4} @ 1$ at $273 \mathrm{~K}$ reveal the passage of $\mathrm{CH}_{4}$ through this material and the selective retention of $\mathrm{CO}_{2}$ (Figure 5). The breakthrough takes place approximately $150 \mathrm{~s}$ after dosing the gas mixture, which represents $0.42 \mathrm{mmol}$ of $\mathrm{CO}_{2}$ being retained per gram of $\mathrm{NH}_{4} @ \mathbf{1}$ under these dynamic conditions. This kind of behavior was expected in view of the differentiated interaction of these two gases with the $\mathrm{NH}_{4} @ 1$ framework (see above). When we performed a similar measurement with $\mathrm{Et}_{3} \mathrm{NH} @ 1$, a related behavior was observed with the breakthrough taking place at about $125 \mathrm{~s}$ and the $\mathrm{CO}_{2}$ removal capacity being diminished to $0.30 \mathrm{mmolg}^{-1}$.

We also studied the effect of ion exchange on the separation selectivity towards benzene/cyclohexane mixtures. The similarity in the boiling points of benzene (b.p. $80.1^{\circ} \mathrm{C}$ )

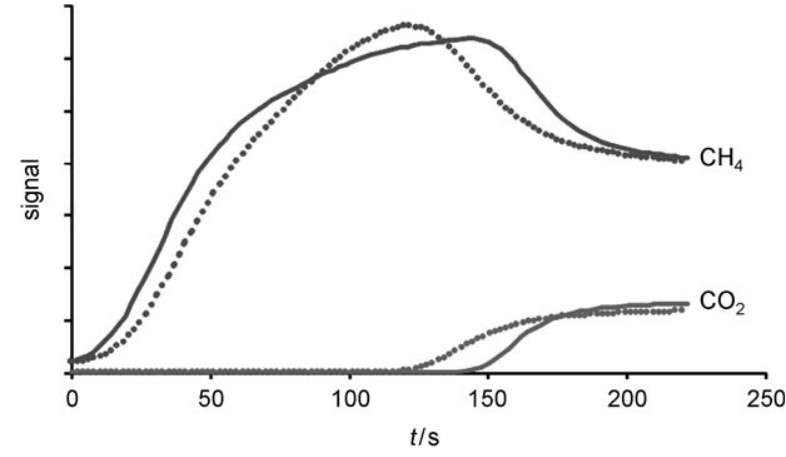

Figure 5. Breakthrough curves for the separation of a 0.27:0.67 (v/v) $10 \mathrm{~mL} \mathrm{~min}^{-1}$ flow of $\mathrm{CO}_{2} / \mathrm{CH}_{4}$ mixture at $273 \mathrm{~K}$ by $\mathrm{NH}_{4} @ 1(-)$ and $\mathrm{Et}_{3} \mathrm{NH} @ 1(\cdot . \cdot \cdot)$.

and cyclohexane (b.p. $80.7^{\circ} \mathrm{C}$ ) makes their separation by distillation inefficient, and consequently separation by shapeselective adsorption is an interesting alternative. Indeed, exposure of the A@1 materials to benzene/cyclohexane 1:1 mixtures shows a significant enrichment of the adsorbate phase in the benzene component. In the case of the original $\mathrm{NH}_{4} @ 1$, the composition of the adsorbed benzene/cyclohexane phase reaches a 5:1 ratio, already showing a clear enrichment in the benzene component. This is further substantiated in the case of the $\mathrm{Et}_{3} \mathrm{NH} @ \mathbf{1}$ and Li@1 materials with benzene/cyclohexane ratios of $8: 1$ and $12: 1$, respectively. The increased selectivity of the $\mathrm{Et}_{3} \mathrm{NH} @ 1$ and Li@1 systems should be related to the increasing bulk of the $\mathrm{Et}_{3} \mathrm{NH}^{+}$and $\mathrm{Li}\left(\mathrm{H}_{2} \mathrm{O}\right)_{4}{ }^{+}$ions.

Finally, we examined the oxidation of cyclohexene and cyclohexane with tert-butyl hydroperoxide as test reactions to evaluate the catalytic activity of $\mathrm{NH}_{4} @ \mathbf{1}^{[18]}$ The results show that $\mathrm{NH}_{4} @ \mathbf{1}$ is catalytically active in both reactions and that the catalyst can be recovered intact from the reaction vessel after the catalytic run (XRPD evidence). Atomic absorption analysis of the filtrate after the catalytic test is also indicative of no copper leaching from $\mathrm{NH}_{4} @ \mathbf{1}$ with the $\mathrm{Cu}^{2+}$ concentration being below $6 \times 10^{-2} \%$ of the initial amount of catalyst. The reaction of cyclohexane $(16 \mathrm{mmol})$ with $t \mathrm{BuOOH}(8 \mathrm{mmol})$ at $70^{\circ} \mathrm{C}$ in the presence of $\mathrm{NH}_{4} @ \mathbf{1}$ gives rise to cyclohexanone as a single product with a yield of $4 \%$ (based on the initial amount of cyclohexane) after $24 \mathrm{~h}$. Moreover, no significant diminution of activity occurs after a second run. It should also be noted that removal of the catalyst after $2 \mathrm{~h}$ leads to a significant decrease of the catalytic activity, similar to the behavior of the blank reaction (see the Supporting Information). In the case of cyclohexene under similar conditions, the results show the formation of different products, namely tert-butyl-2-cyclohexenyl-1-peroxide, followed by 2-cyclohexen-1-one and cyclohexene oxide (see the Supporting Information). The maximum substrate conversion achieved after $15 \mathrm{~h}$ was about $20 \%$ (based on the initial amount of cyclohexene). However, in contrast to the previous case and to the results reported by Volkmer and coworkers,${ }^{[18]}$ we also appreciate a significant progress of the reaction in the absence of the catalyst, namely an approximate $8 \%$ conversion after $4 \mathrm{~h}$ versus $18 \%$ conversion in the presence of catalyst. 
In summary, the results show the formation of the anionic porous framework $\mathrm{NH}_{4} @ \mathbf{1}$. This framework shows reasonably high thermal and chemical stabilities able to withstand the typical conditions found in practical applications. Moreover, it is also possible to modulate its porous network, much like zeolites, by means of cation-exchange processes of the extraframework $\mathrm{NH}_{4}{ }^{+}$cations leading to A@1 materials. The results show that the increasing bulk of the exchanged cations still permits access of molecules to the porous structure with a concomitant increase in size-exclusion selectivity. In this regard, the discrimination properties of the A@1 framework towards complex mixtures, that is, $\mathrm{CO}_{2} /$ $\mathrm{C}_{2} \mathrm{H}_{2} / \mathrm{CH}_{4}$ and $\mathrm{C}_{6} \mathrm{H}_{6} / \mathrm{C}_{6} \mathrm{H}_{12}$, should be highlighted. Finally, we have found that these systems behave as efficient heterogeneous oxidation catalysts, which might be related to the redox-active properties of the $\mathrm{Cu}$ centers and their coordination-unsaturated nature.

\section{Experimental Section}

General experimental methods are summarized in the Supporting Information.

Synthesis of $\mathrm{NH}_{4} @ 1$ : An aqueous ammonia solution $\left(\mathrm{NH}_{3} / \mathrm{H}_{2} \mathrm{O}\right.$ $1: 15,30 \mathrm{~mL})$ containing 4-carboxypyrazole $(2 \mathrm{mmol})$ and $\mathrm{Cu}\left(\mathrm{NO}_{3}\right)_{2}$ ( $2 \mathrm{mmol}$ ) led to a blue solution which afforded in three days dark blue crystals of $\mathrm{NH}_{4} @ \mathbf{1}$ suitable for X-ray diffraction. Elemental analysis calcd (\%) for $\mathrm{NH}_{4}\left[\mathrm{Cu}_{3}(\mathrm{OH})\left(\mathrm{C}_{4} \mathrm{H}_{2} \mathrm{~N}_{2} \mathrm{O}_{2}\right)_{3}\right] \cdot 15 \mathrm{H}_{2} \mathrm{O}: \mathrm{C} 17.45, \mathrm{H} 5.00, \mathrm{~N}$ 11.87; found: C 17.06, H 4.51, N 12.13 .

Received: June 1, 2010

Published online: August 23, 2010

Keywords: gas separation - heterogeneous catalysis . ion exchange $\cdot$ microporous materials . porous coordination polymers

[1] S. R. Batten, S. M. Neville, D. R. Turner, Coordination Poly mers: Design, Analysis and Application, RSC Publishing, Cambridge, 2009.

[2] a) G. Ferey, Chem. Soc. Rev. 2008, 37, 191-241; b) D. Farrusseng, S. Aguado, C. Pinel, Angew. Chem. 2009, 121, 7638 -7649; Angew. Chem. Int. Ed. 2009, 48, 7502-7513.
[3] Z. Wang, S. M. Cohen, Chem. Soc. Rev. 2009, 38, 1315-1329.

[4] A. Phan, C. J. Doonan, F. J. Uribe-Romo, C. B. Knobler, M. O'Keeffe, O. M. Yaghi, Acc. Chem. Res. 2010, 43, 58-68.

[5] M. H. Alkordi, J. A. Brant, L. Wojtas, V. C. Kravtsov, A. J. Cairns, M. Eddaoudi, J. Am. Chem. Soc. 2009, 131, 1775317755 .

[6] J. A. R. Navarro, E. Barea, A. Rodríguez-Diéguez, J. M. Salas, C. O. Ania, J. B. Parra, N. Masciocchi, S. Galli, A. Sironi, J. Am. Chem. Soc. 2008, 130, 3978-3984.

[7] J. A. Greathouse, M. D. Allendorf, J. Am. Chem. Soc. 2006, 128, $10678-10679$.

[8] S. Galli, N. Masciocchi, V. Colombo, A. Maspero, G. Palmisano, F. J. López-Garzón, M. Domingo-García, I. Fernández-Morales, E. Barea, J. A. R. Navarro, Chem. Mater. 2010, 22, 1664-1673.

[9] F. Nouar, J. Eckert, J. F. Eubank, P. Forster, M. Eddaoudi, J. Am. Chem. Soc. 2009, 131, 2864-2866.

[10] Crystal data for $\mathrm{NH}_{4} @ \mathbf{1}: \mathrm{NH}_{4}\left[\mathrm{Cu}_{3}(\mathrm{OH})\left(\mathrm{C}_{4} \mathrm{H}_{2} \mathrm{~N}_{2} \mathrm{O}_{2}\right)_{3}\right] \cdot 8 \mathrm{H}_{2} \mathrm{O}$, $M=700.02$, cubic, space group $F d \overline{3} c, a=30.1955(9) \AA, V=$ 27531(1) $\AA^{3}, Z=32, D_{\text {calc }}=1.351 \mathrm{~g} \mathrm{~cm}^{-3}, T=293 \mathrm{~K}, \lambda \mathrm{Mo}_{\mathrm{K} \alpha}=$ $0.71073 \AA, \quad R_{\text {int }}=0.0617, \quad R\left(F, F^{2}>2 \sigma\right)=0.0841, \quad R w\left(F^{2}, \quad\right.$ all data) $=0.242$ for 1429 unique reflections, goodness-of-fit $=$ 1.099. CCDC 767852 contains the supplementary crystallographic data for this paper. These data can be obtained free of charge from The Cambridge Crystallographic Data Centre via www.ccdc.cam.ac.uk/data_request/cif.

[11] A. L. Spek, J. Appl. Crystallogr. 2003, 36, 7-13.

[12] W. Ouellette, H. Liu, C. J. O'Connor, J. Zubieta, Inorg. Chem. 2009, 48, 4655-4657.

[13] V. A. Blatov, M. O'Keeffe, D. M. Proserpio, Cryst. Eng. Commun. 2010, 12, 44-48.

[14] J.-R. Li, R. J. Kuppler, H.-C. Zhou, Chem. Soc. Rev. 2009, 38, $1477-1504$.

[15] E. Diaz, S. Ordoñez, A. Vega, J. Colloid Interface Sci. 2007, 305 , $7-16$.

[16] a) R. Matsuda, R. Kitaura, S. Kitagawa, Y. Kubota, R. V. Belosludov, T. C. Kobayashi, H. Sakamoto, T. Chiba, M. Takata, Y. Kawazoe, Y. Mita, Nature 2005, 436, 238-241; b) J. P. Zhang, X. M. Chen, J. Am. Chem. Soc. 2009, 131, 55165521; c) S. Xiang, W. Zhou, J. M. Gallegos, Y. Liu, B. Chen, J. Am. Chem. Soc. 2009, 131, 12415-12419.

[17] N. V. Keltsev, The Essential Principles of Adsorption Engineering, Khimia, Moscow, 1984.

[18] M. Tonigold, Y. Lu, B. Bredenkötter, B. Rieger, S. Bahnmüller, J. Hitzbleck, G. Langstein, D. Volkmer, Angew. Chem. 2009, 121, 7682-7687; Angew. Chem. Int. Ed. 2009, 48, 7546-7550. 